Article

\title{
Carbon Asset of Electrification: Valuing the Transition from Fossil Fuel-Powered Buses to Battery Electric Buses in Beijing
}

\author{
Xinkuo $\mathrm{Xu}^{1, *}{ }^{10}$, Xiaofeng $\mathrm{Lv}^{2, *}$ and Liyan $\operatorname{Han}^{3, *}$ \\ 1 School of Finance, Capital University of Economics and Business, Zhangjialukou 121, Beijing 100191, China \\ 2 School of International Business, Southwestern University of Finance and Economics, \\ Chengdu 611130, China \\ 3 School of Economics and Management, Beihang University, Xueyuan Road, Beijing 100191, China \\ * Correspondence: xuxinkuo@cueb.edu.cn or xxkuo@126.com (X.X.); lvxiaofeng81@126.com (X.L.); \\ hanly@buaa.edu.cn (L.H.)
}

Received: 1 April 2019; Accepted: 10 May 2019; Published: 14 May 2019

\begin{abstract}
An increasing number of cities are transitioning from fossil fuel-powered buses for public transport to battery electric buses, but there is still much confusion about the economic evaluation of the electrification of buses, especially in terms of the carbon asset value for carbon emissions reduction in this transition. Taking Beijing as the example, this paper studies the economic value of the transition of public buses from fossil fuel-powered buses to battery electric buses from the perspective of carbon asset theory, and mainly focuses the analysis on direct carbon emissions. First, the theory and methodology of carbon asset evaluation are introduced for the transition from fossil fuel-powered buses to battery electric buses. Second, the internal determinants of the carbon assets for the transition from fossil fuel-powered buses to battery electric buses are studied. Third, the distinct impacts of the determinants of the carbon assets of the transition from fossil fuel-powered buses to battery electric buses are analysed. The results indicate that (1) the transition from fossil fuel-powered buses to battery electric buses has a carbon asset value; (2) the carbon asset value of the transition from fossil fuel-powered buses to battery electric buses is determined by the distance-specific $\mathrm{CO}_{2}$ emissions of fossil fuel-powered buses, the carbon price and the annual driving distances of the buses as well as the discounted rate of the carbon assets for buses and the termination time of the fossil fuel-powered or battery electric buses; and (3) the carbon assets contribute to the economic value of the transition from fossil fuel-powered buses to battery electric buses. This paper provides academic support for the economic evaluation of the transition from fossil fuel-powered buses to battery electric buses in a low-carbon society.
\end{abstract}

Keywords: carbon asset; economic value; fossil fuel-powered buses; battery electric buses; transition; electrification; Beijing

\section{Introduction}

Emission mitigation is one of the major topics of the 21st century [1]. The emissions from road transport have attracted wide publicity, as they cause a severe threat to inner-city air quality and contribute $22 \%$ of the global $\mathrm{CO}_{2}$ emissions [2,3]. As electric automobiles have advantages in energy efficiency, are emission free and produce lower noise levels, the emerging electric buses with decreasing costs are gradually replacing the widely used fossil fuel-powered buses, such as diesel-powered buses $[2,4,5]$. In fact, electric buses have been deployed all across the world, and the electrification of buses is expected to show a strong increasing trend in the near future [6-8]. By early 2018, of the world's 3 million buses, some 385000 were electric, and practically all of them (99\%) were running 
in China, since the replacement of the diesel-fuelled bus with the electric bus was already providing tangible energy and economic benefits [9].

Although an increasing number of cities are transitioning from fossil fuel-powered buses for public transport to battery electric buses [10], the adoption of electric buses globally is geographically uneven and limited in scale [11]. The reason is that the current electric buses still have high production costs and purchase prices $[7,12]$. If the environmental benefits are adequate in consideration, the transition from fossil fuel-powered buses for public transport to electric buses will bring much more benefit to the economy. However, only a few studies have analysed the environmental value in an economic evaluation of electric buses or the electrification of buses [13]. To bridge this gap, the concept of carbon assets is applied to study the value of the contribution of the electrification of buses to the carbon emissions reduction in this paper.

The concept of a carbon asset was proposed to evaluate the economic value of carbon emission reductions in technology, projects, production, consumption, etc. Typical studies include those of Han et al. [14], who evaluated the carbon asset of wind energy technology, and Xu et al. [15], who examined the carbon assets of distributed photovoltaic generation. Based on these studies, this paper further analyses the carbon asset of the transition from fossil fuel-powered buses to battery electric buses (CATFE); it first proposes the theory and methodology of the CATFE evaluation both from an annual view and from the perspective of the whole life cycle. Furthermore, this paper proposes a method to analyse the impacts of the determinants on the annual or whole-life CATFE. Based on the theory and methodology that we propose, this paper then empirically analyses the CATFE in Beijing, where the electrification of buses has an accelerated trend and where the electric power consumption of public transport had an average annual increase of $46.6 \%$ from 2015 to 2017 [16]. By contributing to the understanding of the economic and environmental effects of the transition from fossil fuel-powered buses to battery electric buses from the perspective of carbon asset theory, this study will provide a theoretical basis and academic support for the policy to advocate for the electrification of buses in Beijing as well as in other cities in China and around the world.

The rest of this paper proceeds as follows: Section 2 reviews the literature related to the CATFE. Section 3 introduces the theory and methodology to evaluate the CATFE both from an annual view and a life cycle view and derives the impacts of the influencing factors in the theory. Section 4 introduces the data and variables used in the paper. Section 5 presents the empirical results with some analysis. Section 6 discusses the findings from the empirical results and the significance of understanding the CATFE. Section 7 concludes and discusses the implications of the paper.

\section{Literature Review}

The advantage of carbon reduction for electric buses to replace fossil fuel-powered buses has been studied by many scholars. The most recent literature includes [13,17-19]. Bakker and Konings [17] have referred to battery-electric buses as zero-emission buses, as they result in far less local air pollution than their diesel counterparts [20,21]. Xylia et al. [18] have studied the impact of bus electrification on carbon emissions in Stockholm based on a life cycle perspective and various implementation scenarios. Lee et al. [13] have found that the fuel cell electric transit buses, in comparison with diesel buses, consume less energy overall and have lower air emissions on a well-to-wheel basis in the United States. Rupp et al. [19] have studied the impact of diesel and electric vehicles on $\mathrm{CO}_{2}$ equivalent emissions in Germany from a life-cycle perspective, and they have found that electric vehicles are particularly advantageous in urban traffic because of their positive environmental balance, which is based on greater energy conversion efficiency and the possibility of recuperating the braking energy.

Some other scholars, such as Zhou et al. [21], Li et al. [22], He et al. [23], Dong et al. [24] and Ma et al. [25], have studied the benefit of carbon reduction for electric buses to replace fossil fuel-powered buses in China. Zhou et al. [21] have studied the real-world performance of battery electric buses in Macao and found that an electric bus reduces the diesel bus life-cycle $\mathrm{CO}_{2}$ emissions by $20-35 \%$. Li et al. [22] have also found that the promotion of electric vehicles is an effective way to 
reduce carbon emissions. He et al. [23] have proposed an operating mode binning method to assess the on-road energy consumption and well-to-wheel air pollutant emissions of battery electric buses under complex real-world usage patterns. Dong et al. [24] have studied the low carbon transition of urban public transport in megacities with a case study of Shenzhen. For Beijing, Ma et al. [25] have studied the $\mathrm{CO}_{2}$ emissions reduction of battery electric vehicles including battery electric buses and further analysed the impact factors.

The economic impact of electric buses replacing fossil fuel-powered buses has also been noticed in academia. Lajunen and Lipman [20] have evaluated the lifecycle costs and carbon dioxide emissions of different types of city buses in Finland and California (USA). Mahmoud et al. [26] have reviewed the economic, environmental and other characteristics for hybrid, fuel cell and battery electric buses in detail based on simulation models and operational data presented by various scholars in different contexts. Bakker and Konings [17] have analysed the barriers of zero-emission buses, i.e., the range and costs, and proposed several options for institutional innovation to support the transition to zero-emission buses. Some other scholars, such as Li et al. [27], have analysed the benefits or costs for the carbon emissions reduction of electric buses compared with those of fossil fuel-powered buses. $\mathrm{Li}$ et al. [27] have proposed an approach called the new life additional benefit-cost to analyse the benefits and costs of electric buses compared with those of diesel buses. However, few scholars have examined the economic value of the carbon reduction for electric buses to replace the fossil fuel-powered buses. To bridge this gap, this study applies the carbon asset theory to analyse the economic value of the carbon reduction for the electrification of buses in Beijing.

The carbon asset theory, proposed by Han et al. [14], is a methodology that analyses the economic value of carbon reduction behaviour. Han et al. [14] have evaluated the carbon asset value of wind energy technology and $\mathrm{Xu}$ et al. [15] have analysed the carbon asset value of distributed photovoltaic generation as examples of the application of this theory. Both Han et al. [14] and Xu et al. [15] have further analysed the impacts of the influencing factors for the carbon assets, i.e., the carbon emission reduction level, the production level and the price of carbon. These studies provide references for our evaluation of the carbon asset of the electrification of buses in Beijing in analysing its value and affecting factors. Since there are still no other scholars that have studied the carbon asset of the electrification of buses as far as we know, our study can also be treated as a contribution to the literature that extends the carbon asset theory.

\section{Theory and Methodology}

\subsection{Evaluation of the Annual CATFE Value}

According to Han et al. [14] and Xu et al. [15], the carbon asset value for an entity, such as a technology or a project, is determined by the carbon emissions reduction resulting from the operation of this entity, the industry standard carbon emissions level and the carbon price. Accordingly, the CATFE is determined by the carbon emissions of the battery electric buses, the carbon emissions of the fossil fuel-powered buses and the carbon price for bus companies. To calculate the CATFE, we use the carbon asset value of battery electric buses minus the carbon asset (or debt) value of the fossil fuel-powered buses, which can be written as:

$$
V_{t}=\left(C F_{t}-C E_{t}\right) \times P_{t}
$$

where $V_{t}$ represents the annual CATFE value. $C F_{t}$ is the annual carbon emissions level of a fossil fuel-powered bus, $C E_{t}$ is the annual carbon emissions level of a battery electric bus, and $P_{t}$ is the carbon price at time $t$. We further assume that the battery electric buses are zero-emission entities when focusing on the $\mathrm{CO}_{2}$ emissions directly emitted by the buses. The reasons for this are related to four aspects. First, an electric bus does not emit any gaseous pollutants during transit, which means that the battery electric buses have no direct carbon emissions [9,17]. Second, from a life-cycle carbon footprint perspective, the electric buses certainly do have indirect carbon emissions, as they need electric charging, but the responsibility for reducing the indirect carbon emissions is still being 
debated, and it is difficult to allocate it on an average basis to the specific bodies involved, such as the power plants, the bus companies or the passengers [9]. In fact, with the exception of the passengers, the power plants rather than the bus companies voluntarily or passively bear most of the responsibility for mitigating carbon emissions and other kinds of gaseous emissions in practice or policy-making in China or other countries. Third, the reduction in direct carbon emissions as well as other kinds of gaseous emissions is obvious and is easily measured in the replacement of fossil fuel-powered buses with battery electric buses. Fourth, this assumption will enable the CATFE analysis to be readily understood even though it should be expanded in practice or in future studies. According to this assumption, Equation (1) can be expressed as:

$$
V_{t}^{E}=C F_{t} \times P_{t}
$$

Equation (2) suggests that the annual CATFE value is determined by the baseline level of the annual carbon emissions for a fossil fuel-powered bus and the carbon price at the time. As it is not hard to obtain the carbon price in a public carbon exchange market, the next question is about how to calculate the annual carbon emissions level of a fossil fuel-powered bus.

The carbon emissions level for a fossil fuel-powered bus is determined by the amount of fossil fuel that the bus uses and the carbon emissions level per unit of fossil fuel. The fossil fuel amount the fossil fuel-powered bus uses is determined by the driving distance the battery electric bus travels and the amount of fossil fuel it uses per unit of distance. Accordingly, the annual carbon emissions level of a fossil fuel-powered bus can be written as:

$$
C F_{t}=F U \times C P F \times L_{t}
$$

where $C F_{t}$ represents the annual carbon emissions level of a fossil fuel-powered bus, $L_{t}$ represents the annual driving distance of a bus, CPF is the fossil fuel amount the fossil fuel-powered bus uses per unit of driving distance, and $F U$ is the carbon emissions level per unit of fossil fuel.

We define the carbon emissions level per unit of distance as the distance-specific $\mathrm{CO}_{2}$ emissions for a bus, that is

$$
C E F=F U \times C P F
$$

where $C E F$ is the carbon emissions level per unit of distance, i.e., the distance-specific $\mathrm{CO}_{2}$ emissions of a fossil fuel-powered bus. According to Equations (2)-(4), the annual CATFE value can be written as follows:

$$
V_{t}=C E F \times L_{t} \times P_{t}
$$

Equation (5) suggests that the annual CATFE value is determined by the annual distance travelled by a bus, the carbon price at the time and the distance-specific $\mathrm{CO}_{2}$ emissions of a fossil fuel-powered bus.

\subsection{Evaluation of the Whole-Life CATFE Value}

As battery electric buses and fossil fuel-powered buses may have different usage terminations, it is relatively complex to calculate the total carbon asset value over the life time for both the battery electric buses and fossil fuel-powered buses. Assuming that a fossil fuel-powered bus has a usage termination of time $T$ and that the discount rate is $r$, the value of the whole-life of the CATFE can be written as follows:

$$
V=\sum_{t=0}^{T} V_{t} \times(1+r)^{-t}
$$

where, $V$ represents the whole-life CATFE value, $T$ is the termination time of the fossil fuel-powered bus, and $r$ is the discount rate of the carbon asset for buses. 
According to Equations (1), (2), (4), (5) and (6), there is

$$
V=\sum_{t=0}^{T} C E F \times L_{t} \times P_{t} \times(1+r)^{-t}
$$

Assuming the same annual driving distance for both the fossil fuel-powered buses and battery electric buses, a constant carbon price for all the bus companies, a constant carbon emissions baseline for the fossil fuel-powered buses and a zero-emission assumption same to Equation (2) for the battery electric buses, i.e.,

$$
\begin{aligned}
L_{t} & =L \\
P_{t} & =P \\
C B_{t} & =C B
\end{aligned}
$$

then, Equation (7) changes to

$$
V=C E F \times L \times P \times \sum_{t=0}^{T}(1+r)^{-t}
$$

where $V$ represents the whole-life CATFE value, CEF is the distance-specific $\mathrm{CO}_{2}$ emissions of a fossil fuel-powered bus, $L$ is the annual distance travelled of a bus, $P$ is the carbon price, $T$ is the termination time of the fossil fuel-powered bus, and $r$ is the discount rate of the carbon asset for buses. Equation (8) implies the variables that determine the whole-life CATFE value.

\subsection{Effects of the Determinants on the CATFE Value}

After obtaining the determinants for the annual and whole-life CATFE values, it is interesting to analyse which determinants have larger effects on the carbon asset value. To analyse the impacts of the determinants, we first take the derivatives of $V_{t}$ with respect to $P_{t}, L_{t}$, and CEF according to Equation (5), i.e.,

$$
\begin{aligned}
& \frac{d V_{t}}{d P_{t}}=C E F \times L_{t} \\
& \frac{d V_{t}}{d L_{t}}=C E F \times P_{t} \\
& \frac{d V_{t}}{d C E F}=L_{t} \times P_{t}
\end{aligned}
$$

and then take the derivatives of $V$ with respect to $P, L$ and $C E F$ according to Equation (8), i.e.,

$$
\begin{aligned}
& \frac{d V}{d P}=C E F \times L \times \sum_{t=0}^{T}(1+r)^{-t} \\
& \frac{d V}{d L}=C E F \times P \times \sum_{t=0}^{T}(1+r)^{-t} \\
& \frac{d V}{d C E F}=L \times P \times \sum_{t=0}^{T}(1+r)^{-t}
\end{aligned}
$$

Equations (9)-(14) can be used to analyse the impacts of the annual driving distance of either a battery electric or fossil fuel-powered bus ( $L_{t}$ or $L$, respectively), the carbon price ( $P_{t}$ or $P$, respectively) and the distance-specific $\mathrm{CO}_{2}$ emissions of a fossil fuel-powered bus (CEF) on the annual and whole-life CATFE values. 


\section{Data and Variables}

This section describes the data and variables for calculating the annual and whole-life CATFE values in Beijing. To evaluate the annual CATFE values in Beijing, we need to know its determinants. According to Equation (5), the determinants include the annual driving distance of a bus, the carbon price and the distance-specific $\mathrm{CO}_{2}$ emissions of a fossil fuel-powered bus, as the distance-specific carbon emissions for a battery electric bus are nearly to zero when focusing on the direct carbon emissions. According to Equation (8), the whole-life CATFE value in Beijing is further determined by the discounted rate of a carbon asset for buses and the termination time of the fossil fuel-powered or battery electric buses as well.

\subsection{Distance-Specific $\mathrm{CO}_{2}$ Emissions of Fossil Fuel-Powered Buses}

The distance-specific $\mathrm{CO}_{2}$ emissions of a fossil fuel-powered bus, according to Equation (3), are equal to the fossil fuel amount that the fossil fuel-powered bus uses per unit of distance multiplied by the carbon emissions level per unit of fossil fuel. Zhang et al. [28] have collected the on-road testing profiles for 75 heavy-duty transit buses including groups with diesel, CNG, LNG and hybrid diesel engines in Beijing. They have obtained some of the average real-world fuel consumption and $\mathrm{CO}_{2}$ emission factors for the tested vehicle groups under a typical driving cycle, and we calculate the rest of the parameters according to their results. Table 1 shows the results of the distance-specific energy usage of the diesel, CNG, LNG and hybrid diesel buses and the related distance-specific $\mathrm{CO}_{2}$ emissions of these buses, which reflects the distance-specific $\mathrm{CO}_{2}$ emissions of different types of fossil fuel-powered buses. Zhang et al. [28] have also studied the distance-specific energy usage of diesel buses with different standards, i.e., the Euro II, Euro III, Euro IV, and Euro V diesel buses. According to the distance-specific energy usage of the diesel buses with different standards, we calculate the distance-specific $\mathrm{CO}_{2}$ emissions of these buses as shown in Table 1 . These results can be used to reflect the distance-specific $\mathrm{CO}_{2}$ emissions of the diesel buses with different standards or as the industry standard distance-specific $\mathrm{CO}_{2}$ emissions for the buses.

Table 1. Distance-specific $\mathrm{CO}_{2}$ emissions of each type of fossil fuel-powered bus in Beijing.

\begin{tabular}{ccc}
\hline Type of Bus & FU & CEF \\
\hline CNG Buses & $16.1 \pm 4.9 \mathrm{MJ} \mathrm{km}^{-1 *}$ & $932 \pm 234 \mathrm{~g} \mathrm{~km}^{-1 *}$ \\
\hline LNG Buses & $14.1 \pm 0.7 \mathrm{MJ} \mathrm{km}^{-1 *}$ & $837 \pm 43 \mathrm{~g} \mathrm{~km}^{-1 *}$ \\
\hline Hybrid Diesel Buses & $8.9 \pm 0.1 \mathrm{MJ} \mathrm{km}^{-1 *}$ & $658 \pm 7 \mathrm{~g} \mathrm{~km}^{-1 *}$ \\
\hline Diesel Buses (all) & $11.8 \pm 2.6 \mathrm{MJ} \mathrm{km}^{-1 *}$ & $871 \pm 198 \mathrm{~g} \mathrm{~km}^{-1 *}$ \\
\hline Euro II Diesel Buses & $11.1 \pm 3.4 \mathrm{MJ} \mathrm{km}^{-1 *}$ & $823 \pm 252 \mathrm{~g} \mathrm{~km}^{-1 \#}$ \\
\hline Euro III Diesel Buses & $11.5 \pm 1.8 \mathrm{MJ} \mathrm{km}^{-1 *}$ & $852 \pm 133 \mathrm{~g} \mathrm{~km}^{-1 \#}$ \\
\hline Euro IV Diesel Buses & $12.4 \pm 3.0 \mathrm{MJ} \mathrm{km}^{-1 *}$ & $919 \pm 222 \mathrm{~g} \mathrm{~km}^{-1 \#}$ \\
\hline Euro V Diesel Buses & $10.7 \pm 0.3 \mathrm{MJ} \mathrm{km}^{-1 *}$ & $793 \pm 22 \mathrm{~g} \mathrm{~km}^{-1 \#}$ \\
\hline
\end{tabular}

Note: The data with * are sourced by Zhang et al. [28]. The data with \# are calculated by the authors according to the data in the first column and the coefficient of $\mathrm{CO} 2$ emissions per unit diesel oil a bus uses, i.e., $74.10 \mathrm{~g} / \mathrm{MJ}$, according to Wang et al. [29].

\subsection{Price of Carbon}

In addition to the carbon reduction level, the carbon price is another factor influencing the transition of public buses from diesel to battery electric. The statistics that characterise the carbon price in Beijing are based on the price data sourced from the Beijing Carbon Emission Allocation (BEA) Electronic Trading Platform [30]. The price of the common carbon emissions, except for the forest carbon sink and China Certified Emission Reduction Credit (CCER), has an average price of 55.64 Yuan, a minimum value of 30.32 Yuan, a maximum value of 74.6 Yuan, and a standard deviation 
of 10.84 Yuan according to the 145 transactions that occurred in Beijing in 2018, as shown in Figure 1 . We use these data to represent the price of the carbon asset of replacing the diesel public buses with battery electric buses.

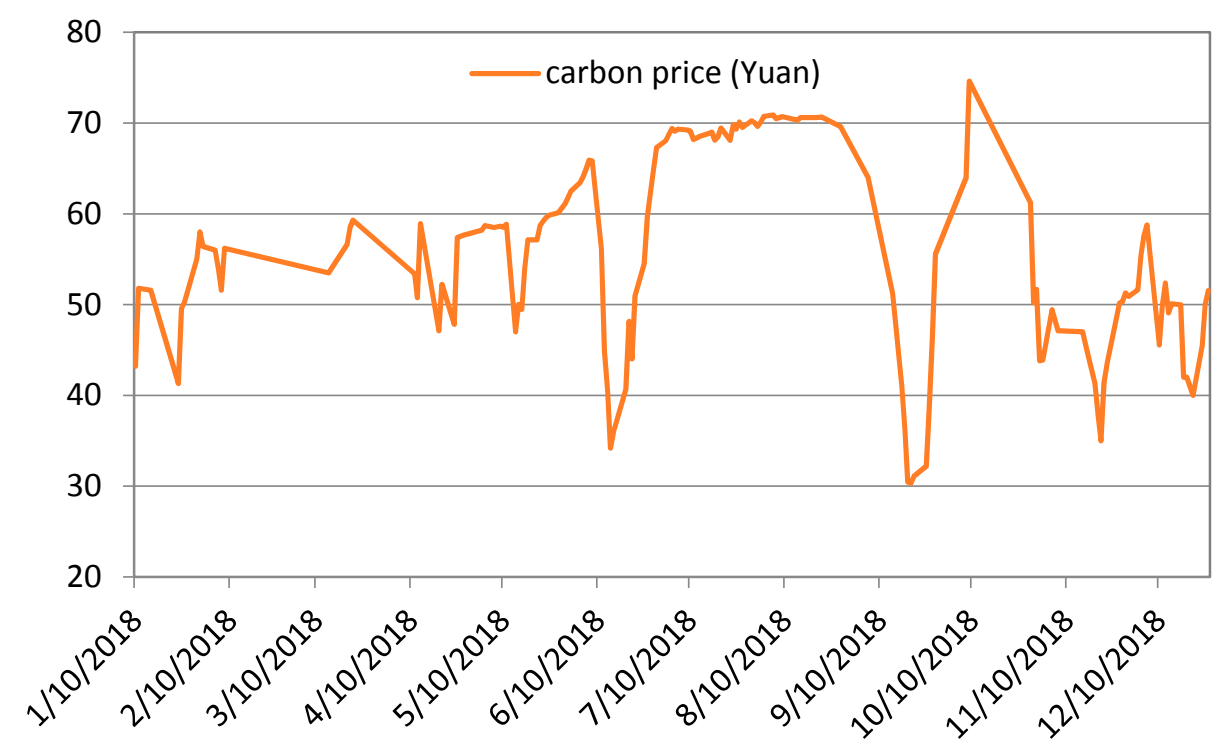

Figure 1. The price of common carbon emissions enacted in Beijing in 2018.

\subsection{Other Variables}

The average annual driving distance of a public bus is $57,962 \mathrm{~km}$ according to the statistical data [31]. These data are used to represent the annual driving distance of a bus in Beijing $(L)$. The yield rate of a 5-year treasury bond was approximately $4.75 \%$ in China in February, 2019, and this value is used to represent the discount rate of the carbon asset value in this paper (i.e., $r$ ). The service life of a public bus is usually 8 years, which is used to represent the termination time of the fossil fuel-powered bus in this paper.

\section{Empirical Results and Analysis}

\subsection{The Annual CATFE Value in Beijing}

The annual CATFE value $\left(V_{t}\right)$ is determined by the annual driving distance of a bus $\left(L_{t}\right)$, the carbon price at the time $\left(P_{t}\right)$ and the distance-specific $\mathrm{CO}_{2}$ emissions of a fossil fuel-powered bus (CEF), as Equation (5) shows. We substitute the variables from Section 4 into Equation (5) and estimate the annual carbon asset value of the transition from different types of fossil fuel-powered buses to battery electric buses in Beijing. As shown in Section 4.1, the statistics of the distance-specific $\mathrm{CO}_{2}$ emissions for the different types of fossil fuel-powered buses in Beijing, including the mean and fluctuation values, are shown in Table 1. Section 4.2 shows the carbon price in Beijing, which has an average value of 55.64 Yuan, a minimum value of 30.32 Yuan and a maximum value of 74.6 Yuan. Section 4.3 shows that the average annual driving distance of a bus is $57,962 \mathrm{~km}$, i.e., $L=57,962 \mathrm{~km}$. Accordingly, one can obtain the annual carbon asset value of the transition from different types of fossil fuel-powered buses to battery electric buses in Beijing. Table 2 shows the results for the average carbon price and the average distance-specific $\mathrm{CO}_{2}$ emissions for the different types of fossil fuel-powered buses with fluctuations. To express the results more intuitively, we further draw Figure 2 based on the data from Table 2. 
Table 2. Annual carbon asset value of the transition between fossil fuel-powered buses with different types and battery electric buses in Beijing.

\begin{tabular}{cc}
\hline Type of Bus & Annual Carbon Asset Value \\
\hline CNG Buses & $3005.71 \pm 754.65$ Yuan \\
\hline LNG Buses & $2699.33 \pm 138.68$ Yuan \\
\hline Hybrid Diesel Buses & $2122.05 \pm 22.58$ Yuan \\
\hline Diesel Buses (all) & $2808.98 \pm 638.55$ Yuan \\
\hline Euro II Diesel Buses & $2654.18 \pm 812.70$ Yuan \\
\hline Euro III Diesel Buses & $2747.71 \pm 428.93$ Yuan \\
\hline Euro IV Diesel Buses & $2963.78 \pm 715.95$ Yuan \\
\hline Euro V Diesel Buses & $2557.43 \pm 70.95$ Yuan \\
\hline
\end{tabular}

Note: The results are calculated according to Equation (5) when the carbon price gets its average value, i.e., $P_{t}=55.64$ Yuan, and the distance-specific $\mathrm{CO}_{2}$ emissions for the different types of fossil fuel-powered buses get the mean values with fluctuations as Table 1 shows.

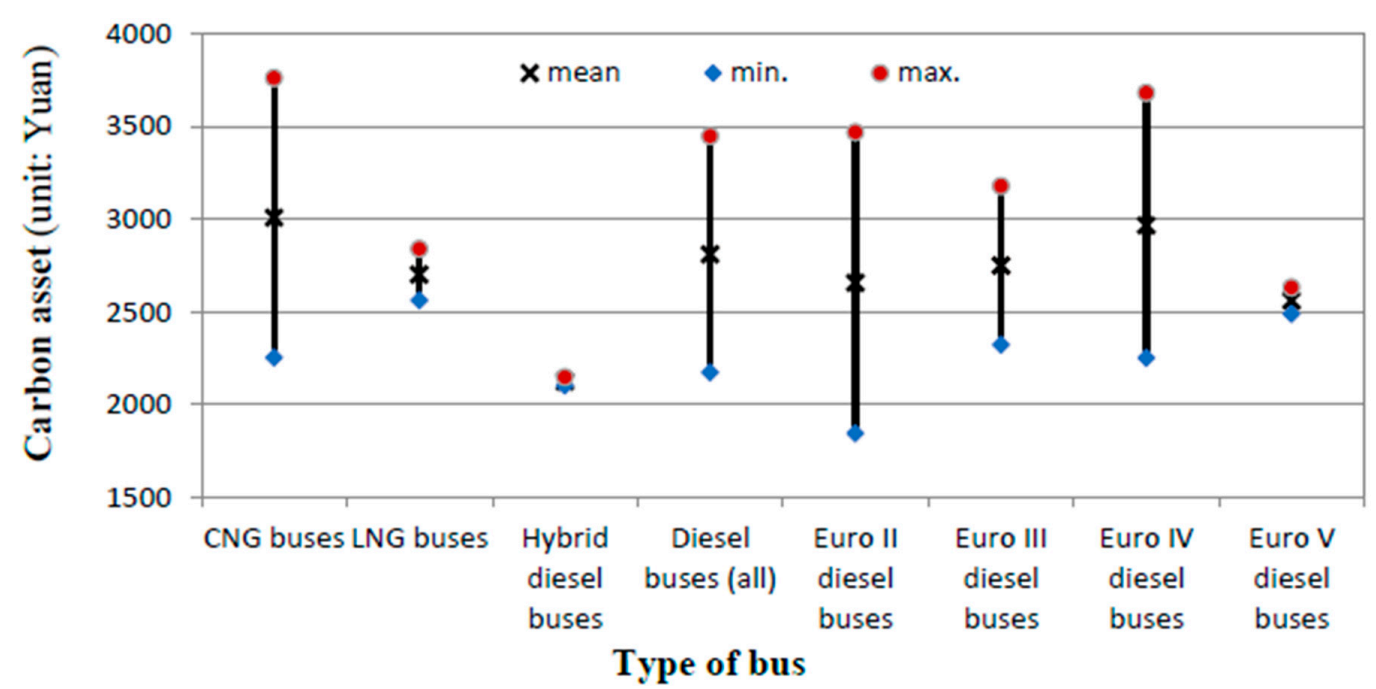

Figure 2. Annual carbon asset value of the transition between fossil fuel-powered buses with different types and battery electric buses in Beijing.

Table 2 and Figure 2 illustrate that the annual carbon asset of the transition to battery electric buses in Beijing has different values and fluctuations for the different types of fossil fuel-powered buses according to Equation (5) and the variables from Section 4. For the four types of fossil fuel-powered buses including the CNG, LNG, Hybrid diesel and diesel buses, the transition from CNG buses to battery electric buses has the highest average annual carbon asset value and fluctuation, which is $3005.71 \pm 754.65$ Yuan. The next-highest is the transition from diesel buses to battery electric buses, whose average annual carbon asset value and fluctuation are $2808.98 \pm 638.55$ Yuan. The third-highest is the transition from LNG buses to battery electric buses, whose average annual carbon asset value and fluctuation are $2699.33 \pm 138.68$ Yuan. The transition from hybrid diesel buses to battery electric buses has the lowest average annual carbon asset value, which is 2122.05 Yuan. These results suggest that the transition from CNG buses has the highest annual value in Beijing in terms of the carbon asset, followed by the transitions from the diesel buses and the LNG buses. The hybrid diesel buses, which already use some electrical power, have the lowest annual value for the transition to battery electric buses. In fact, the hybrid diesel buses have a lower probability of being replaced by the battery electric buses because of the advantages of energy selection compared with the other types of fossil fuel-powered buses. 
The diesel buses are further divided into four types, i.e., the Euro II, Euro III, Euro IV and Euro V diesel buses, according to the emission standard. Table 2 and Figure 2 also show the results for the annual carbon asset evaluation for the different types of diesel buses in Beijing when replaced by the battery electric buses. The transition from the Euro IV diesel buses to the battery electric buses has the highest average annual carbon asset value, which is 2963.78 Yuan per year. The next-highest are the Euro III diesel buses with an average annual carbon asset value of 2747.71 Yuan per year and the Euro II diesel buses with an average annual carbon asset value of 2747.71 Yuan per year. The Euro V diesel buses have the lowest average annual carbon asset value when replaced by battery electric buses in Beijing. These results suggest the range of values for the different types of diesel buses when replaced by battery electric buses in Beijing.

As one of the determinants, the carbon price has an impact on the CATFE value. When the carbon price has different values, the CATFE value will change. We thus assume that the distance-specific $\mathrm{CO}_{2}$ emissions for a particular type of fossil fuel-powered buses have a constant value, i.e., the mean value; then, we analyse the annual CATFE value in Beijing for the mean, minimum and maximum carbon price values. The results are shown in Table 3, and we draw Figure 3 to illustrate the results more intuitively.

Table 3. Annual carbon asset value of the transition between fossil fuel-powered buses and battery electric buses when the carbon price changes in Beijing.

\begin{tabular}{cccc}
\hline Type of Bus & Mean & Min & Max \\
\hline CNG Buses & 3005.705 & 1637.904 & 4029.94 \\
\hline LNG Buses & 2699.33 & 1470.95 & 3619.16 \\
\hline Hybrid Diesel Buses & 2122.054 & 1156.37 & 2845.17 \\
\hline Diesel Buses (all) & 2808.98 & 1530.70 & 3766.17 \\
\hline Euro II Diesel Buses & 2654.18 & 1446.35 & 3558.62 \\
\hline Euro III Diesel Buses & 2747.71 & 1497.311 & 3684.02 \\
\hline Euro IV Diesel Buses & 2963.78 & 1615.06 & 3973.72 \\
\hline Euro V Diesel Buses & 2557.43 & 1393.62 & 3428.90 \\
\hline
\end{tabular}

Note: The unit for the variables in this table is Yuan per year.

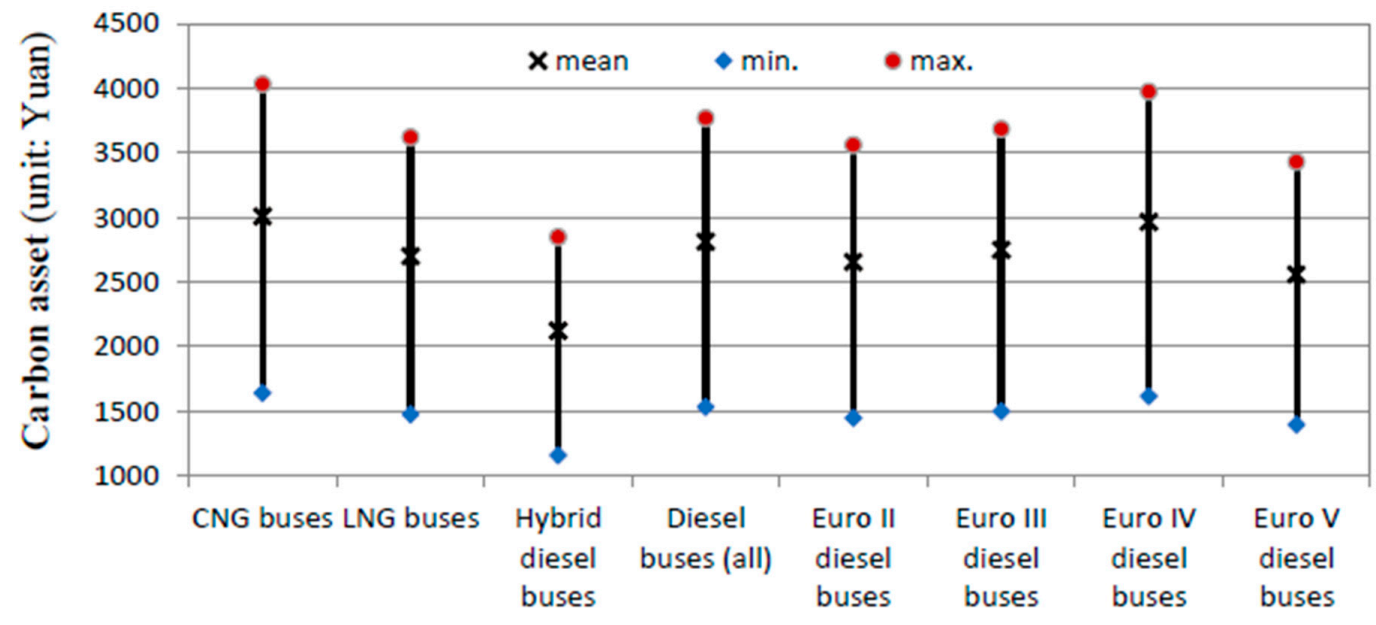

Type of bus

Figure 3. Annual carbon asset value of the transition between fossil fuel-powered buses and battery electric buses when the carbon price changes in Beijing. 
Table 3 and Figure 3 illustrate that the carbon asset of the transition to battery electric buses has different mean, maximum and minimum annual values for the different types of fossil fuel-powered buses when the carbon price in Beijing changes. For the four types of fossil fuel-powered buses including the CNG, LNG, Hybrid and diesel buses, the transition from CNG buses to battery electric buses has the highest average, maximum and minimum annual carbon asset values. The next-highest is the transition from the diesel buses and the LNG buses. The transition from the hybrid diesel buses to battery electric buses has the lowest average, maximum, and minimum annual carbon asset values. For the different types of diesel buses, the transition from the Euro IV diesel buses to battery electric buses has the highest average, maximum and minimum annual carbon asset values in Beijing. The next-highest is the transition from the Euro III diesel buses and the Euro II diesel buses. The Euro V diesel buses have the lowest average annual carbon asset value when replaced by the battery electric buses in Beijing. The maximum and minimum values of the annual carbon assets of the transition to battery electric buses have the same order for the different types of fossil fuel-powered buses in Beijing. However, the annual carbon assets of the transition to battery electric buses in Beijing have similar fluctuation extents for all the types of fossil fuel-powered buses as the carbon price changes. The reason is that the carbon price change is the same for the different types of fossil fuel-powered buses.

\subsection{Value of the Whole-Life CATFE in Beijing}

According to Equation (8), the whole-life CATFE value $(V)$ is determined by the carbon emissions level per unit of fossil fuel (FU), distance-specific $\mathrm{CO}_{2}$ emissions of a fossil fuel-powered bus (CPF), annual driving distance of a bus $(L)$, carbon price $(P)$, termination time of a fossil fuel-powered bus $(T)$, and discounted rate of the carbon asset for buses $(r)$. We substitute the variables from Section 4 into Equation (8) and estimate the whole-life carbon asset value of the transition from different types of fossil fuel-powered buses to battery electric buses in Beijing. The results are shown in Table 4.

Table 4 shows the whole-life carbon asset value of the transition to battery electric buses for the different types of fossil fuel-powered buses for different values of the carbon price and distance-specific $\mathrm{CO}_{2}$ emissions for the various types of fossil fuel-powered buses. When the carbon price achieves the average value, i.e., $P_{t}=55.64$ Yuan, and when the distance-specific $\mathrm{CO}_{2}$ emissions for the different types of fossil fuel-powered buses achieve mean values, the average whole-life CATFE value changes from 14,409 Yuan to 20,409 Yuan for the different types of fossil fuel-powered buses. When the carbon price achieves the average value and when the distance-specific $\mathrm{CO}_{2}$ emissions for the different types of fossil fuel-powered buses achieve their minimum values, the average whole-life CATFE value changes from 12,504 Yuan to 17,387 Yuan for the different types of fossil fuel-powered buses. When the carbon price achieves the average value and the distance-specific $\mathrm{CO}_{2}$ emissions for the different types of fossil fuel-powered buses achieve their maximum values, the average whole-life CATFE value changes from 14,562 Yuan to 25,533 Yuan for the different types of fossil fuel-powered buses. When the carbon price achieves the minimum value, i.e., $P_{t}=30.32$ Yuan, and the distance-specific $\mathrm{CO}_{2}$ emissions for the different types of fossil fuel-powered buses achieve the mean values, the average whole-life CATFE value changes from 7,852 Yuan to 11,121 Yuan for the different types of fossil fuel-powered buses. When the carbon price achieves the maximum value, i.e., $P_{t}=74.60$ Yuan, and the distance-specific $\mathrm{CO}_{2}$ emissions for the different types of fossil fuel-powered buses achieve the mean values, the average whole-life CATFE value changes from 19,319 Yuan to 27,363 Yuan for the different types of fossil fuel-powered buses.

Table 4 shows that, for each type of fossil fuel-powered bus, the whole-life CATFE value has distinct changes, while the carbon price or the distance-specific $\mathrm{CO}_{2}$ emissions get different values. For the CNG buses, the average whole-life CATFE value changes from 11,121 Yuan to 27,363 Yuan. For the LNG buses, the average whole-life CATFE value changes from 9,988 Yuan to 24,574 Yuan. For the hybrid diesel buses, the average whole-life CATFE value changes from 7,852 Yuan to 19,319 Yuan. For the diesel buses, the average whole-life CATFE value changes from 110,393 Yuan to 25,572 Yuan. For the different types of diesel buses, the average whole-life CATFE values have distinct changes 
when the carbon price or the distance-specific $\mathrm{CO}_{2}$ emissions have different values. For the different types of fossil fuel-powered buses, the minimum and maximum whole-life CATFE values are mainly determined by the changes in the carbon price, although the distance-specific $\mathrm{CO}_{2}$ emissions also influence these values.

Table 4. Whole-life carbon asset value of the transition to battery electric buses for different types of fossil fuel-powered buses in Beijing.

\begin{tabular}{cccccc}
\hline Type of Bus & Mean & Min (Fuel) & Max (Fuel) & Min (Price) & Max (Price) \\
\hline CNG Buses & 20,409 & 15,285 & 25,533 & 11,121 & 27,363 \\
\hline LNG Buses & 18,328 & 17,387 & 19,270 & 9988 & 24,574 \\
\hline Hybrid Diesel Buses & 14,409 & 14,255 & 14,562 & 7852 & 19,319 \\
\hline Diesel Buses (all) & 19,073 & 14,737 & 23,409 & 10,393 & 25,572 \\
\hline Euro II Diesel Buses & 18,022 & 12,504 & 23,540 & 9821 & 24,163 \\
\hline Euro III Diesel Buses & 18,657 & 15,745 & 21,569 & 10,167 & 25,014 \\
\hline Euro IV Diesel Buses & 20,124 & 15,263 & 24,985 & 10,966 & 26,982 \\
\hline Euro V Diesel Buses & 17,365 & 16,883 & 17,847 & 9463 & 23,282 \\
\hline
\end{tabular}

Note: The unit for the variables in this table is Yuan per year, and the results in the five columns are all calculated according to Equation (8). The results in the first column are gathered according to when the carbon price achieves the average value, i.e., $P_{t}=55.64$ Yuan, and as Table 1 shows, the distance-specific $\mathrm{CO}_{2}$ emissions for the different types of fossil fuel-powered buses also achieve mean values. The results in the second column are gathered according to when the carbon price achieves the average value and the distance-specific $\mathrm{CO}_{2}$ emissions for the different types of fossil fuel-powered buses achieve their minimum values. The results in the third column are gathered according to when the carbon price achieves the average value and the distance-specific $\mathrm{CO}_{2}$ emissions for the different types of fossil fuel-powered buses achieve their maximum values. The results in the fourth column are gathered according to when the carbon price achieves the minimum value, i.e., $P_{t}=30.32$ Yuan, and the distance-specific $\mathrm{CO}_{2}$ emissions for the different types of fossil fuel-powered buses also achieve the mean values. The results in the fifth column are gathered according to when the carbon price achieves the maximum value, i.e., $P_{t}=74.60$ Yuan, and the distance-specific $\mathrm{CO}_{2}$ emissions for the different types of fossil fuel-powered buses also achieve the mean values.

\subsection{Impacts of the Determinants on the CATFE Value in Beijing}

The next step is to analyse the impacts of the determinants on the CATFE value in Beijing. According to Equations (9)-(14), we analyse how the changes in the annual driving distance of a bus $\left(L_{t}\right)$, the carbon price at the time $\left(P_{t}\right)$ and the distance-specific $\mathrm{CO}_{2}$ emissions of a fossil fuel-powered bus $(C E F)$ affect the annual or whole-life carbon asset value of the transition to battery electric buses for the different types of fossil fuel-powered buses. By substituting the variables from Section 4 into Equations (9), (10), (12) and (13), we obtain the results for the impacts of the carbon price or the annual driving distance of a bus on the annual and whole-life CATFE value for the different types of fossil fuel-powered buses, which are shown in Table 5.

Table 5 shows that the carbon price $\left(P_{t}\right)$ affects the annual CATFE value with derivative values between 38.14 and 54.02, while the annual driving distance of a bus $\left(L_{t}\right)$ has derivative values between 0.0366 and 0.0519 in terms of the change in the annual CATFE value. This means that a one-unit change in the carbon price will induce the annual CATFE value to change from 38.14 to 54.02 for the different types of fossil fuel-powered buses. A one-unit change in the annual driving distance of a bus will only induce the annual CATFE value to change from 0.0366 to 0.0519 for the different types of fossil fuel-powered buses. These results suggest that a change in the carbon price will induce the annual CATFE value to change much more than a change in the annual driving distance of any type of fossil fuel-powered bus, although the carbon price or the annual driving distance of a bus has distinct impacts on the carbon asset value of the transition to battery electric buses for the different types of fossil fuel-powered buses.

Similarly, Table 5 also shows that the carbon price affects the whole-life CATFE value with the derivative values between 258.96 and 366.80, while the annual driving distance of a bus $\left(L_{t}\right)$ has derivative values between 0.2486 and 0.3521 in terms of the change in the whole-life CATFE value. 
This means that a one-unit change in the carbon price will induce a whole-life CATFE value change from 258.96 to 366.80 for the different types of fossil fuel-powered buses, and a one-unit change in the annual driving distance of a bus will only induce a whole-life CATFE value change from 0.2486 to 0.3521 for the different types of fossil fuel-powered buses. These results suggest that a change in the carbon price will induce the whole-life CATFE value to change much more than a change in the annual driving distance of a fossil fuel-powered bus, although the carbon price and the annual driving distance of a bus have distinct impacts on the whole-life carbon asset value of the transition to battery electric buses for the different types of fossil fuel-powered buses.

Table 5. Whole-life carbon asset value of the transition to battery electric buses for different types of fossil fuel-powered buses in Beijing.

\begin{tabular}{ccccc}
\hline Type of Bus & $\begin{array}{c}\text { Derivative of } \\
\text { Annual CATFE } \\
\text { Value with } \\
\text { Respect to Price }\end{array}$ & $\begin{array}{c}\text { Derivative of } \\
\text { Annual CATFE } \\
\text { Value with } \\
\text { Respect to the } \\
\text { Annual Driving } \\
\text { Distance of a Bus }\end{array}$ & $\begin{array}{c}\text { Derivative of } \\
\text { Whole-Life } \\
\text { CATFE Value with } \\
\text { Respect to Price }\end{array}$ & $\begin{array}{c}\text { Derivative of } \\
\text { Whole-Life } \\
\text { CATFE Value with } \\
\text { Respect to the } \\
\text { Annual Driving } \\
\text { Distance of a Bus }\end{array}$ \\
\hline CNG buses & 54.02 & 0.0519 & 366.80 & 0.3521 \\
LNG buses & 48.51 & 0.0466 & 329.41 & 0.3162 \\
Hybrid diesel buses & 38.14 & 0.0366 & 258.96 & 0.2486 \\
Diesel buses (all) & 50.48 & 0.0485 & 342.79 & 0.3291 \\
Euro II diesel buses & 47.70 & 0.0458 & 323.90 & 0.3109 \\
Euro III diesel buses & 49.38 & 0.0474 & 335.31 & 0.3219 \\
Euro IV diesel buses & 53.27 & 0.0511 & 361.68 & 0.3472 \\
Euro V diesel buses & 45.96 & 0.0441 & 312.09 & 0.2996 \\
\hline
\end{tabular}

Note: By substituting the variables from Section 4 into Equation (9), the results in the first column are achieved. Similarly, by substituting the variables from Section 4 into Equation (10), Equation (12) and Equation (13), the results in the second, third or fourth columns are achieved.

By substituting the variables from Section 4 into Equations (11) and (14), the results for the impacts of the distance-specific $\mathrm{CO}_{2}$ emissions of a fossil fuel-powered bus on the annual and whole-life CATFE value in Beijing are achieved. According to our calculation, the distance-specific $\mathrm{CO}_{2}$ emissions of a fossil fuel-powered bus affect the annual CATFE value with a derivative value of $3.22 \times 10^{6}$ and the whole-life CATFE value with a derivative value of $2.19 \times 10^{7}$. This indicates that a change in the distance-specific $\mathrm{CO}_{2}$ emissions of a fossil fuel-powered bus will have a large impact on the CATFE value, even though a change in the distance-specific $\mathrm{CO}_{2}$ emissions of buses does not happen easily in a short time.

\section{Discussion}

\subsection{Determinants of the CATFE Value}

According to Section 5.3 in this paper, the distance-specific $\mathrm{CO}_{2}$ emissions of a fossil fuel-powered bus, among all the determinants of the CATFE value, have the biggest impact on the annual or whole-life CATFE value, followed by the carbon price. The annual driving distance of a bus only has a small impact on the CATFE value. The distance-specific $\mathrm{CO}_{2}$ emissions of a fossil fuel-powered bus are nearly constant over short time periods. However, if we consider the indirect $\mathrm{CO}_{2}$ emissions of battery electric buses, the impact of the distance-specific $\mathrm{CO}_{2}$ emissions of buses on the CATFE value should be explored further. The carbon price fluctuations are volatile in the carbon market. Thus, more attention should be given to the carbon price when trying to improve the CATFE value. When calculating the CATFE value in Beijing, we use the carbon price in Beijing in 2018, which has an average of 55.64 Yuan. In fact, the carbon price in Beijing before 2018 was higher than that in 2018 and in other places in China, such as Fujian. As a result, the CATFE value will increase when carbon prices rise. 


\subsection{Realiseation of the CATFE Value}

The development of the carbon exchange market provides the realiseation of the CATFE value. In China, there are eight pilot carbon exchange markets in provinces or cities such as Beijing, Shanghai, Shenzhen, Hubei and, Fujian, and the united carbon market is going to be implemented. The carbon exchange mechanisms have also been attempted or implemented in Europe, America and some other countries and regions around the world. The practice of the Clean Development Mechanism (CDM) around the world, which allows emission-reduction projects in developing countries to earn certified emission reduction (CER) credits, will provide much more valuable experience for the evaluation, sale and trade of CATFEs.

\subsection{Significance of the CATFE Value}

The CATFE value will provide economic incomes for bus companies. Compared with the subsidy policies for battery buses, the CATFE value will provide a more sustainable cash flow. A CATFE will have a more reasonable price when being exchanged in a carbon market, and the bus companies will change their motivation to transition their fossil fuel-powered buses to battery electric buses when the carbon price changes. The carbon price, in fact, provides a signal for the bus companies to make a decision concerning the electrification of buses by the CATFE mechanism. The CATFE mechanism will be more efficient than the subsidy policies for battery electric buses. As a result, the CATFE mechanism will have a better carbon emissions reduction effect in the public bus transit domain. At the very least, the CATFE value will offer a reference and foundation for determining the subsidy price if the subsidy policies for battery electric buses continue.

\section{Conclusions and Policy Implications}

This paper introduces the concept and methodology of carbon assets into the transition from fossil fuel-powered buses to battery electric buses and further analyses the influencing factors and their impacts on the value of the carbon asset of the transition from fossil fuel-powered buses to battery electric buses (CATFE). The specific conclusions are as follows:

First, the theory and methodology of the carbon asset value can be used to evaluate the economic value of the carbon reduction in the transition from fossil fuel-powered buses to battery electric buses. There are advantages with regard to carbon reduction for the battery electric buses compared with the fossil fuel-powered buses, as the battery electric buses emit little carbon dioxide directly. The carbon asset theory provides a methodology to evaluate the economic value of the electrification of buses.

Second, according to the evaluation models in our analysis, the CATFE value is dependent on the annual driving distance of a bus, the carbon price and the distance-specific $\mathrm{CO}_{2}$ emissions of a fossil fuel-powered bus as well as the discounted rate of a carbon asset for buses and the termination time of the fossil fuel-powered or battery electric buses. The annual CATFE value is dependent on the annual driving distance of a bus, the carbon price and the distance-specific $\mathrm{CO}_{2}$ emissions of a fossil fuel-powered bus. The whole-life CATFE value is further dependent on the discounted rate of a carbon asset for buses and the termination time of the fossil fuel-powered or battery electric buses.

Third, among the determinants of the CATFE value, the distance-specific $\mathrm{CO}_{2}$ emissions of the fossil fuel-powered buses have the biggest impact on the annual or whole-life CATFE value, but it is not easy to change the distance-specific $\mathrm{CO}_{2}$ emissions of a fossil fuel-powered bus in a short time period. The carbon price has the second most important impact on the CATFE value, and it has volatile fluctuations in the carbon market. Therefore, more attention should be given to the carbon price when referring to the value of the CATFE. The annual driving distance of a bus has a small impact on the CATFE value. The discounted rate of a carbon asset for buses and the termination time of the fossil fuel-powered or battery electric buses need further discussion in a future study. 
By applying the concept of carbon asset theory to the transition from fossil fuel-powered buses to battery electric buses, this study provides a wider perspective for understanding the social, ecological and environmental values and eventually provides a supplement for the economic analysis of the electrification of buses. Based on the analysis and conclusions of this study, as well as the existing policies and state of development of the electrification of buses in China, we propose the following policy implications:

Although the subsidy policies for electric buses have already been implemented in China and some other countries, the basis for the standard-setting is still very disorganised in theory and practice. The finding of the CATFE value provides a more theoretical basis for the government to implement subsidy policies for the electrification of buses. Moreover, this study provides theoretical support for the government to propose a carbon exchange mechanism for the electrification of buses, which will be more efficient for the purpose of carbon reduction than the subsidy policies for electric buses.

An important issue for the government and bus companies is how to increase the value of the CATFE, as a higher CATFE value will accelerate the electrification of buses and reduce carbon emissions even more. By analysing the impact factors, this study implies the ways to improve the CATFE value. The government should set a reasonable quota for fossil fuel-powered buses and promote the carbon emissions reduction of battery electric buses. A higher carbon price for the carbon emissions reduction of battery electric buses is another way to increase the CATFE value. There should be ways for the bus companies to increase and realise this value through a carbon exchange mechanism or a carbon-reduction subsidy system.

This study also enriches the methodologies for the government and bus companies as well as other market partners to evaluate the CATFE value and the value of other carbon assets for renewable engines. According to our methodology for valuing the CATFE, the carbon price, distance-specific $\mathrm{CO}_{2}$ emissions and annual driving distance of buses as well as the discounted rate of carbon assets for buses and the termination time of the fossil fuel-powered or battery electric buses should be considered. An analysis should focus more on the distance-specific $\mathrm{CO}_{2}$ emissions of buses in the long term, while the CATFE value is more sensitive to the carbon price in the short term. The annual driving distance of buses, the discounted rate of carbon assets for buses and the termination time of the fossil fuel-powered or battery electric buses should also be considered in practice. As we focus on the direct $\mathrm{CO}_{2}$ emissions and assume that the battery electric buses are zero-emission buses, the CATFE value in a life-cycle carbon footprint view is still to be further discussed in a future study.

Author Contributions: Conceived, designed, and performed the experiments, analysed the data, wrote the paper and revised the paper, X.X.; partly performed the experiments, analysed the data and revised the paper, X.L.; designed the research, supervised the whole process and revised the paper, L.H. All authors have read and approved the final manuscript.

Funding: This work was supported by the National Natural Science Foundation of China (71603174, 71501159, $71803139,71690244)$, the National Social Science Foundation of China (16AZ014, 16CJY040) and the Youth Top-notch Team Project of Beijing Outstanding Talents Training Fund (2016000026833TD02).

Acknowledgments: The authors are very grateful to have the paper manuscript reviewed by the journal editors and reviewers.

Conflicts of Interest: The authors declare no conflict of interest.

\section{References}

1. Rogge, M.; van der Hurk, E.; Larsen, A.; Sauer, D.U. Electric bus fleet size and mix problem with optimization of charging infrastructure. Appl. Energy 2018, 211, 282-295. [CrossRef]

2. Teoh, L.E.; Khoo, H.L.; Goh, S.Y.; Chong, L.M. Scenario-based electric bus operation: A case study of Putrajaya, Malaysia. Int. J. Transp. Sci. Technol. 2018, 7, 10-25. [CrossRef]

3. Miles, J.; Potter, S. Developing a viable electric bus service: The Milton Keynes demonstration project. Res. Transp. Econ. 2014, 48, 357-363. [CrossRef] 
4. Vepsäläinen, J.; Otto, K.; Lajunen, A.; Tammi, K. Computationally efficient model for energy demand prediction of electric city bus in varying operating conditions. Energy 2019, 169, 433-443. [CrossRef]

5. Ye, L.; Liang, C.; Liu, Y.; Li, D.; Liu, Z. Performance analysis and test of a novel eddy-current braking \& heating system for electric bus. Energy Convers. Manag. 2019, 183, 440-449.

6. Xylia, M.; Silveira, S. The role of charging technologies in upscaling the use of electric buses in public transport: Experiences from demonstration projects. Transp. Res. Part A Policy Pract. 2018, 118, 399-415. [CrossRef]

7. Wei, R.; Liu, X.; Ou, Y.; Fayyaz, S.K. Optimising the spatio-temporal deployment of battery electric bus system. J. Transp. Geogr. 2018, 68, 160-168. [CrossRef]

8. He, H.; Yan, M.; Sun, C.; Peng, J.; Li, M.; Jia, H. Predictive air-conditioner control for electric buses with passenger amount variation forecast. Appl. Energy 2018, 227, 249-261. [CrossRef]

9. Pagliaro, M.; Meneguzzo, F. Electric bus: A critical overview on the dawn of its widespread uptake. Adv. Sustain. Syst. 2019, 1800151. [CrossRef]

10. Marc, G.; Tobias, M.; Thomas, H. Estimation of the energy demand of electric buses based on real-world data for large-scale public transport networks. Appl. Energy 2018, 230, 344-356.

11. Li, X.; Castellanos, S.; Maassen, A. Emerging trends and innovations for electric bus adoption-A comparative case study of contracting and financing of 22 cities in the Americas, Asia-Pacific, and Europe. Res. Transp. Econ. 2018, 69, 470-481. [CrossRef]

12. Lajunen, A. Lifecycle costs and charging requirements of electric buses with different charging methods. J. Clean. Prod. 2018, 172, 56-67. [CrossRef]

13. Lee, D.; Elgowainy, A.; Vijayagopal, R. Well-to-wheel environmental implications of fuel economy targets for hydrogen fuel cell electric buses in the United States. Energy Policy 2019, 128, 565-583. [CrossRef]

14. Han, L.; Liu, Y.; Lin, Q.; Huang, G. Valuing carbon assets for high-tech with application to the wind energy industry. Energy Policy 2015, 87, 347-358. [CrossRef]

15. Xu, X.; Guan, C.; Jin, J. Valuing the carbon assets of distributed photovoltaic generation in China. Energy Policy 2018, 121, 374-382. [CrossRef]

16. Beijing Public Transport Corporation. Travelling Together: Beijing Public Transport Corporation Social Responsibility Report 2017; Beijing Public Transport Corporation: Beijing, China, 2018; Available online: http://www.bjbus.com/home/index.php (accessed on 26 May 2018).

17. Bakker, S.; Konings, R. The transition to zero-emission buses in public transport-The need for institutional innovation. Transp. Res. Part D Transp. Environ. 2018, 64, 204-215. [CrossRef]

18. Xylia, M.; Leduc, S.; Laurent, A.B.; Patrizio, P.; Van Der Meer, Y.; Kraxner, F.; Silveira, S. Impact of bus electrification on carbon emissions: The case of Stockholm. J. Clean. Prod. 2019, 209, 74-87. [CrossRef]

19. Rupp, M.; Handschuh, N.; Rieke, C.; Kuperjans, I. Contribution of country-specific electricity mix and charging time to environmental impact of battery electric vehicles: A case study of electric buses in Germany. Appl. Energy 2019, 237, 618-634. [CrossRef]

20. Lajunen, A.; Lipman, T. Lifecycle cost assessment and carbon dioxide emissions of diesel, natural gas, hybrid electric, fuel cell hybrid and electric transit buses. Energy 2016, 106, 329-342. [CrossRef]

21. Zhou, B.; Wu, Y.; Zhou, B.; Wang, R.; Ke, W.; Zhang, S.; Hao, J. Real-world performance of battery electric buses and their life-cycle benefits with respect to energy consumption and carbon dioxide emissions. Energy 2016, 96, 603-613. [CrossRef]

22. Li, W.; Jia, Z.; Zhang, H. The impact of electric vehicles and CCS in the context of emission trading scheme in China: A CGE-based analysis. Energy 2016, 119, 800-816. [CrossRef]

23. He, X.; Zhang, S.; Ke, W.; Zheng, Y.; Zhou, B.; Liang, X.; Wu, Y. Energy consumption and well-to-wheels air pollutant emissions of battery electric buses under complex operating conditions and implications on fleet electrification. J. Clean. Prod. 2018, 171, 714-722. [CrossRef]

24. Dong, D.; Duan, H.; Mao, R.; Song, Q.; Zuo, J.; Zhu, J.; Wang, G.; Hu, M.; Dong, B.; Liu, G. Towards a low carbon transition of urban public transport in megacities: A case study of Shenzhen, China. Resour. Conserv. Recycl. 2018, 134, 149-155. [CrossRef]

25. Ma, Y.; Ke, R.Y.; Han, R.; Tang, B.J. The analysis of the battery electric vehicle's potentiality of environmental effect: A case study of Beijing from 2016 to 2020. J. Clean. Prod. 2017, 145, 395-406. [CrossRef]

26. Mahmoud, M.; Garnett, R.; Ferguson, M.; Kanaroglou, P. Electric buses: A review of alternative powertrains. Renew. Sustain. Energy Rev. 2016, 62, 673-684. [CrossRef] 
27. Li, L.; Lo, H.K.; Xiao, F.; Cen, X. Mixed bus fleet management strategy for minimizing overall and emissions external costs. Transp. Res. Part D Transp. Environ. 2018, 60, 104-118. [CrossRef]

28. Zhang, S.; Wu, Y.; Liu, H.; Huang, R.; Yang, L.; Li, Z.; Fu, L.; Hao, J. Real-world fuel consumption and $\mathrm{CO}_{2}$ emissions of urban public buses in Beijing. Appl. Energy 2014, 113, 1645-1655. [CrossRef]

29. Wang, Z.; Chen, F.; Fujiyam, T. Carbon emission from urban passenger transportation in Beijing. Transp. Res. Part D Transp. Environ. 2015, 41, 217-227. [CrossRef]

30. Beijing Carbon Emission Allocation (BEA) Electronic Trading Platform. Available online: http://www.bjets. com.cn/article/jyxx/ (accessed on 10 May 2019).

31. Song, Q.; Wang, Z.; Wu, Y.; Li, J.; Yu, D.; Duan, H.; Yuan, W. Could urban electric public bus really reduce the GHG emissions: A case study in Macau? J. Clean. Prod. 2018, 172, 2133-2142. [CrossRef]

C 2019 by the authors. Licensee MDPI, Basel, Switzerland. This article is an open access article distributed under the terms and conditions of the Creative Commons Attribution (CC BY) license (http://creativecommons.org/licenses/by/4.0/). 